удК $\quad 316.344 .24: 338.124 .4(497.11) " 1921 / 1931 "$

DOI https://doi.org/10.31212/tokovi.2019.3.raf.79-104

Оригинални научни рад

Примљен: 1. 9. 2019.

Прихваћен: 16. 9. 2019.

Jelena RAFAILOVIĆ

Faculty of Philosophy, University of Belgrade jelena.rafailovic@f.bg.ac.rs

\title{
Economic Structure of the Population in the Kingdom of SCS *
}

\begin{abstract}
This paper deals with the economic structure of the population in the Kingdom of Serbs, Croats, and Slovenes/Yugoslavia mostly based on two censuses taken in 1921 and 1931. The topic has been addressed at demographic and economic levels through the analysis of various indicators with the aim of presenting a young country through the statistics of a basic economic segment, for the purpose of understanding its economic and social situation.
\end{abstract}

Key words: Kingdom of SCS, Population, Demographics, Economy, Census

The Kingdom of Serbs, Croats, and Slovenes has been addressed and studied from different perspectives using different thematic and methodological approaches, but one of the segments that has rarely been studied and analyzed is the economic situation. This article aims to present the economic structure of the population as a basic economic segment in a decade after the creation of the Kingdom, encompassing the years for which data is available in the censuses from 1921 to 1931. The economic structure of the population is a reflection of the economic situation in the country, conditioned by the structure of the economy and society and influencing the functioning of the state. In Serbian and Yugoslav historiography, this topic is more or less presented in all syntheses that deal with the

This article has been produced within the framework of the project: Tradition and Transformation - Historical Heritage and National Identities in Serbia in the $20^{\text {th }}$ Century (№ 47019), funded by the Ministry of Education, Science, and Technological Development of the Republic of Serbia. 
economy of the Kingdom of SCS/Yugoslavia, as well as in individual studies or monographs that address the issue of population within the region, or that deal with demographic changes before and after World War I, ${ }^{1}$ for which information is listed. "How big will our Yugoslavia be and what will it be like? - Every day the same questions from all sides; and hardly anyone could answer this question because it was not easy, indeed. Yugoslavia comprised thirteen different regions, some of them only partly, making the creation of a unique picture even more difficult." ${ }^{2}$ The situation as presented by Joso Lakatoš in 1919 still reflected this problem and that is the reason why presenting and analyzing the economic structure of the population after the creation of the Kingdom is important for the understanding of the new state that included several different economic entities.

\section{Sources and Research Methods}

Displaying and measuring the level of economic development through population structure is a challenging and technically complex issue. Population censuses are of primary importance for analyzing the economic structure of the population, followed by other statistical publications such as birth, death and marriage registers, registers of individual

1 Момчило Исић, Социјална и аграрна структура Србије у Краљевини Југославији (према попису становништва од 31. марта 1931. године), (Београд: Институт за новију историју Србије, 1999); Sergije Dimitrijević, Privredni razvitak Jugoslavije od 1918-1941 godine, (Beograd: Visoka škola političkih nauka, 1961); Mijo Mirković, Ekonomska struktura Jugoslavije: 1918-1941, (Zagreb: Školska knjiga, 1952); Borče Ilievski, "Turci u Kraljevini SCS/Jugoslaviji. Demografska analiza na osnovu popisa stanovništva 1921. i 1931", Istorija 20. veka 1/2018, 35-54; Milka Bubalo-Živković, Bojan Đerčan, "Demographic changes in the Kingdom of SCS and the Kingdom of Yugoslavia", Историја и географија: сусрети и прожимања, ур. Софија Божић, (Београд: Институт за новију историју Србије, Географски институт “Јован Цвијић” САНУ, Институт за славистику РАН, 2014), 299-317; Владан Јовановић, “Демографске одлике Вардарске бановине и проблеми самоидентификације”; Etnoantropološki problem 2/2012, 563-584; Никола Л. Гаћеша, “Демографске и социјалне прилике у време присаједињења Војводине Краљевини Србији 1918. године", Присаједињење Војводине Краљевини Србији 1918, (Нови Сад: Музеј Војводине, Институт за историју Филозофског факултета, 1993), 49-57; Никола Л. Гаћеша, Радови из аграрне историје и демографије, (Нови Сад: Матица српска, 1995); Bogoljub Kočović, Etnički i demografski razvoj u Jugoslaviji od 1921. do 1991. godine: (po svim zvaničnim a u nekim slučajevima i korigovanim popisima), sv. 1, (Paris: Association Dialogue, 1998).

2 Joso Lakatoš, Jugoslavija u svijetlu statistike, (Zagreb: Tisak hrvatskog štamparskog zavoda, 1919), 2. 
services, surveys and the like. ${ }^{3}$ The most important for analyzing the economic structure of the Kingdom of SCS are national population censuses, which represent "a large-scale statistical project that includes collecting information about the state of the population throughout the country over a given period of time," ${ }^{4}$ thus providing comprehensive and uniform data. ${ }^{5}$ They comprise data on the population's biological structure - gender and age; economic structure - occupation, field of operation, economic activity, but also on the social, intellectual, cultural, educational, and ethnic structure. ${ }^{6}$ However, the use of censuses in the Kingdom of SCS/Yugoslavia entailed a number of problems and certain methodological limitations. The first problem was that the statistical service was not based in one institution or ministry. It frequently changed from one governing authority to another, which along with territorial and administrative changes influenced the absence of continuous statistical series and a lack of significant information that would otherwise be provided by summary statistics. The lack of statistical material is partly the result of the political division of the country up to 1918 , and partly due to the lack of a clearly defined, legally framed and organized central statistical institution. ${ }^{7}$ Beside the question of institutionalization of the statistical service,

3 Dragoslav Mladenović, Vladislav Đolević, Dejan Šoškić, Ekonomska statistika, (Beograd: Centar za izdavačku delatnost Ekonomskog fakulteta, 2008), 36-37; Valentina Sokolovska, Ekonomska struktura stanovništva Republike Srbije, (Novi Sad: Filozofski fakultet, 2018), 9, date of access 25. 8. 2019, http://digitalna.ff.uns. ac.rs/sadrzaj/2018/978-86-6065-469-6)

$4 \quad$ Mladenović, Đolević, Šoškić, Ekonomska statistika, 33.

5 Simon Kuznets, Economic Growth and Structure, (London: Heinemann Educational Books, 1966), 11-12. - When analyzing historical macroeconomic aggregate data, such as censuses, particular attention should be paid to the inconsistency of the data and the question whether they are a representation of those data that the state wanted and/or could present. Heinz-Gerhard Haupt, Jurgen Kocka, "Historijska poredba: metode, zadaci i problemi. Uvod", Uvod u komparativnu historiju, prir. Drago Roksandić, (Zagreb, 2004), 170-171.

6 Mladenović, Đolević, Šoškić, Ekonomska statistika, 40, 67.

7 The territories on which the Kingdom was formed had different internal organizations, which made it difficult to unify and organize the statistical service. In the Kingdom, the statistical service was split between several ministries. In 1919, the Directorate of National Statistics was established within the Ministry of Social Policy as an independent body and the Directorate was immediately joined by the of National Statistics of the Kingdom of Serbia, as well as Montenegro and Southern Serbia, which did not have their own statistical offices. In 1924 it was accessed by the then independent statistical sections from the formerly Austro-Hungarian provinces. The Directorate of National Statistics was transferred to the Ministerial Council in 1929 and changed its name to General State Statistics, and in 1931 it became part of the Ministry of the Interior. (Мари Жанин Чалић, Социјална историја Србије, 18151941, успорени напредак у индустријализацији, (Београд: Clio, 2004), 25; Miroslav 
there was also the question to which extent the censuses reflected the state policy and the real situation in the country. According to S. Radovanović, the censuses in Yugoslavia "reflected the goals of national politics in the spirit of Yugoslavism." One form of such a policy was the administrative-territorial model of organization based on the division of the state into banovinas (banates) in 1929, which, with the exception of Slovenia and partly the Littoral, failed to match administrative with historical and geographical areas. ${ }^{8}$

This paper is based primarily on the censuses of 31 January 1921 and 31 March 1931, and to a lesser extent on the Yearbook of the Kingdom of SCS of $1926 .{ }^{9}$ As to the census of 31 January 1921, there are a few things to be mentioned regarding its publishing. It was first published as Preliminary Results of the Census in the Kingdom of Serbs, Croats, and Slovenes of 31 January 1921 by the Government Statistics Directorate, Sarajevo 1924, and then as Final Results of the Census of the Kingdom of Serbs,

Paskojević, "Statistička služba u Jugoslaviji", Socijalni arhiv 8/1937, 159; Stevan Kukoleča, Industrija Jugoslavije 1918-1938, (Beograd: Balkanska štampa, 1941), 1).

8 Светлана Радовановић, „Етничка структура Краљевине Југославије у контексту националне политике југословенства“, Демографија IV/2007, 130; See also: Zoran Janjetović, Deca careva, pastorčad kraljeva, Nacionalne manjine u Jugoslaviji 1918-1945, (Beograd: Institut za noviju istoriju Srbije, 2005), 62-82. - Due to the administrative changes in the Kingdom of Serbs, Croats, and Slovenes, it is not possible to continuously monitor the territorial principle, but due to the importance and broader understanding of the Yugoslav economy, data are also presented at the territorial level according to the "historical" areas, although they are presented according to the then provincial division. Upon its establishment, the Kingdom of Serbs, Croats, and Slovenes was territorially and administratively divided into seven provinces, namely: North Serbia (within the borders of the Kingdom of Serbia until the Balkan Wars); South Serbia (territories annexed after the Balkan Wars, with the districts of Berane, Bijelo Polje, Pljevlje and Metohija); Slovenia (Kranjska, Koruška, Štajerska, Prekomurje); Croatia and Slavonia with Međumurje, the island of Krk and the municipality of Kastav (along with Srem and Zemun); Banat, Bačka, Baranja; Dalmacia (with Kotor county); Bosnia-Herzegovina; Montenegro. In April 1922, a Decree on the Division of the Country into Regions was brought according to which the territory of the Kingdom of SCS was divided into 33 regions. The next territorial and administrative division was made in 1929 when the regions were abolished and 9 banovinas of Vardar, Vrbas, Drava, Drina, Danube, Zeta, Morava, Littoral, Sava were established as well as the City Administration of Belgrade. During 1931 and 1932, the borders of banovinas were corrected and minor territorial changes were made. (“Уредба о подели земље на области”, Службене новине Краљевине Срба, Хрвата и Словенаца IV, 92, 28. 4. 1922, 1-2; “Закон о називу и подели Краљевине на управна подручја", Службене новине Краљевине Југославије XI, 232, 4. 10. 1929, 1-2; Светлана Радовановић, “Два века пописне статистике у Србији”, Демографија 2/2005, 38-40).

9 Годишњак Краљевине Срба, Хрвата и Словенаца 1926, ур. Добр. Стошовић, (Београд: Н. Т. Montague bell, 1926). 
Croats, and Slovenes of 31 January 1921 by General State Statistics, Belgrade 1932. There are some discrepancies between these two editions with reference to the size of the territory and the population. The first edition lists the number 12,017,323 and the second one 11,984,911 with a difference of about 32,412 people; the state territory in the Preliminary Results is $248,987 \mathrm{~km}^{2}$, compared to $248,666 \mathrm{~km}^{2}$ in the Final Results, the difference being $322 \mathrm{~km}^{2}$. The difference lies in the fact that the Final Results do not show territories that did not belong to the Kingdom of SCS during its definitive delineation. After the reduction of its territory, the corrected data were used and subsequently published in the Statistical Yearbooks of the Kingdom of Yugoslavia.$^{10}$ Also, due to the state's new administrative division in 1929, the data by territories were presented differently, which causes a significant problem for continuous monitoring of data and a more detailed analysis, especially given the changes in historical borders during the twentieth century in the territory of Yugoslavia.

The aforementioned lack of reliable statistical data makes direct measuring of a number of economic characteristics impossible, but leaves space for the use of indirect indices of economic situation in the analysis. One of these indices is population statistics, which is most often present in economically less developed countries, because other information on economic activities is very scarce or non-existent. The lack of adequate economic and demographic statistics itself can be considered as one of the indicators of economic underdevelopment. ${ }^{11}$ Considering the nature of the statistical material produced by the censuses of 1921 and 1931, the economic structure of the population will be analyzed at two levels, demographic: the population's size, growth, and structure, mortality, age structure, distribution in the cities, ${ }^{12}$ and economic: economically active and inactive population and population structure by occupation. It is also possible to analyze some other data from the census, but given the limitations of space and type of article, the aim is to present only basic economic and demographic indicators and provide a basis for further study on the topic.

10 Definitivni rezultati popisa stanovništva od 31. januara 1921. god, (Beograd: Opšta državna statistika, Sarajevo: Državna štamparija, 1932), V-VI; Радовановић, „Етничка структура Краљевине“, 133.

11 Philip M. Hauser, "Demographic Indicators of Economic Development", Economic Development and Cultural Change 7, 2 (1959), 98.

12 The above indicators are some of population indices covering the components of population growth, changes in population, composition and distribution of population (Hauser, "Demographic Indicators", 100). 
Due to the character of available material, demographic statistics, this paper uses a branch of statistics similar to descriptive statistics. ${ }^{13}$ In terms of historical statistics, i.e. the use of statistics in the study of historical processes and events, this paper uses a descriptive and quantitative model.

\section{Demographic indicators}

The rate of population growth is one of the most significant demographic measurements of economic state and development; it is not an economic indicator, but a strategic indicator in relation to other demographic categories: natality, mortality and migration, and a basic variable when it comes to other economic measurements. ${ }^{14}$

In the long term perspective, the population from the territory of the Kingdom of SCS until World War I had an unprecedented growth rate, and in the period between the two wars, this high rate continued. The death rate began to decline in the second half of the $19^{\text {th }}$ century with the birth rate still at a high level, meaning that the Kingdom of SCS and the Balkans had entered the second phase of demographic transition. ${ }^{15} \mathrm{Be}-$ tween the censuses taken in 1921 and 1931, the population in the Kingdom of SCS increased from 11,984,911 to $13,934,038$, which is an increase of 1,949,127 in absolute numbers or $16.2 \%$ with an annual growth rate of $1.5 \%$ (Table 1). The number of people per square kilometer increased from 48.4 to 56.2 , while a single household had an average of 5 members. ${ }^{16}$

Natural growth was not the same in all parts of the Kingdom of SCS. Bosnia-Herzegovina, i.e. the Drinska banovina and the Vrbaska banovina, were ahead, while Slovenia, the Dravska banovina and the territory of Vojvodina and the Dunavska banovina had the smallest population growth.

13 These are: average number of population, total absolute population growth, average annual absolute population growth, relative population growth (arithmetic rate) and average geometric population growth rate (Mladenović, Đolević, Šoškić, Ekonomska statistika, 32)

14 Hauser, "Demographic Indicators", 101; See also: Simon, Kuznets, "Population and Economic Growth", Proceedings of the American Philosophical Society 111, 3, Population Problems, 1967, 170-193.

15 Leften Stavrijanos, Balkan posle 1453. godine, (Beograd: Equilibrium, 2005), 567.

16 Statistički godišnjak I, 1929, (Beograd: Opšta državna statistika Kraljevine Jugoslavije, 1932), 57, 100-111; Statistički godišnjak IV, 1932, (Beograd: Opšta državna statistika Kraljevine Jugoslavije, 1934), 47. 
Table 1: Demographic structure of the population in $1921,{ }^{17}$ population in banovinas in 1921 and 1931

\begin{tabular}{|l|c|c|c|c|c|c|c|}
\hline Provinces & Male & Female & Total & Banovina & 1921 & 1931 & CAGR \\
\hline North Serbia & $47.96 \%$ & $52.04 \%$ & $2,656,731$ & Drava & $1,060,356$ & $1,144,298$ & $0.76 \%$ \\
\hline South Serbia & $49.86 \%$ & $50.14 \%$ & $1,476,747$ & Drina & $1,205,500$ & $1,534,739$ & $2.44 \%$ \\
\hline Montenegro & $49.73 \%$ & $50.27 \%$ & 199,227 & Danube & $2,179,329$ & $2,387,295$ & $0.92 \%$ \\
\hline Bosnia-Her- & $51.11 \%$ & $48.89 \%$ & $1,890,440$ & Morava & $1,200,258$ & $1,435,584$ & $1.81 \%$ \\
\hline cegovina & $49.32 \%$ & $50.68 \%$ & 620,432 & Littoral & 804,163 & 901,660 & $1.15 \%$ \\
\hline Dalmatia & $48.74 \%$ & $51.26 \%$ & $2,739,888$ & Sava & $2,424,374$ & $2,704,383$ & $1.10 \%$ \\
\hline Croatia & $49.03 \%$ & $50.97 \%$ & $11,984,911$ & Zeta & 784,693 & 925,516 & $1.66 \%$ \\
\hline Banat, Bačka \\
Baranja
\end{tabular}

Sources: Definitivni rezultati popisa stanovništva od 31. januara 1921. god, 368-379, 382385; Statistički godišnjak IV, 1932, 40-41.

World War I significantly affected the population's demographic and economic structure, but not in the same way on all the territories of the new Kingdom. This was mainly due to the loss of the population in the

17 The difference in the census data refers to the registered and unregistered part of the population in Dalmatia for which there is no information on gender and age structure. 
Kingdom of Serbia. ${ }^{18}$ This also affected the population's economic structure in the first years after the war, as men between 15 and 54 years of age, most of the workforce, accounted for less than a quarter of the Serbian population in 1921, and part of the population returning from the war were veterans partially or completely unable to work. ${ }^{19}$

The components of population change related to mortality and birth rate can be displayed only to some extent, since not all information is available in censuses. Mortality is one of the best indicators of economic status and development. A decrease in mortality rate and a decrease in mortality in general are closely linked to increased economic activity. ${ }^{20}$ Also, important indicators of the economic situation are different types of mortality, such as: infant mortality, deaths of children under five as a percentage of the total deaths; deaths of persons over 50 as a percentage of the total deaths, but also analysis of mortality by cause, migration and the like. ${ }^{21}$

The average mortality rate in the Kingdom of SCS between 1919 and 1929 was 20.3, and varied over the years, the lowest being during 1925 and 1926, when it started increasing again. In absolute numbers, an average number of 258,334 people died per year, the least number dying in $1925(239,428)$ and the most in $1929(286,227) .{ }^{22}$ According to official statistics, most of them died of tuberculosis and other epidemic and infectious diseases. ${ }^{23}$ In the period after war 1921-1925, mortality indices

18 For more details, see: Милош Јагодић, “Процена демографских губитака Срба у периоду 1910-1921. године”, Српске студије 6/2015, 11-65.

19 Miloš Jagodić, Ognjen Radonjić, "Pyrrhic Victory: The Great War and its Immediate Consequences for Serbia's Economy", The Economic Causes and Consequences of the First World War, eds Ivan Vujačić, Mihail Arandarenko, (Belgrade: Ekonomski fakultet, Centar za izdavačku delatnost, 2015), 225-227.

20 Edward G. Stockwell, "Fertility, Mortality, and Economic Status of Underdeveloped Areas", Social Forces 41, No. 4, 1963, 390-395.

21 Studies of demographic, social and economic indicators after World War II showed that in less developed countries, deaths from parasitic and infectious diseases constitute a relatively high proportion of all mortality, while in more developed countries, a high proportion of all deaths is attributable to degenerative causes - coronary diseases, cancer, and the like. Hauser, "Demographic Indicators", 104.

22 Statistički godišnjak I, 1929, 118-119.

23 In a small number of cases, the cause of death was determined by a doctor and in most cases by a registrar who recorded a cause of death according to the statement of the family, so it is impossible to have completely accurate information (Statistički godišnjak I, 1929, 119). 
were similar in all SEE countries, out of 1,000 people, 20.8 died in Bulgaria, 19.9 in Hungary, 23 in Romania, and 16.5 in Greece. ${ }^{24}$

The average number of deaths of infants under one year of age in the period from 1925 to 1929 amounted to 66,386, and from statistical points of view, $14.5 \%$ of those who were born alive died by the age of one, which is about 145 per 1,000 children born alive. The decline in infant mortality was not so significant to be interpreted as an indicator of a better economic situation in the country; from 1924 to 1926 the mortality rate decreased, but in 1926, it increased again..$^{25}$ The mortality rate was higher than in most developed European countries, and according to the classification of the League of Nations, Yugoslavia was among the countries with a very high infant mortality. ${ }^{26}$ Compared to other countries ${ }^{27}$ there were 117 deaths per 1,000 live births in Austria, ${ }^{28} 83$ in France, ${ }^{29}$ 104 in Germany, ${ }^{30} 192$ in Romania, 172 in Hungary, 147 in Bulgaria, and 122 in Greece. ${ }^{31}$ Yugoslavia was characterized, not only by a high infant mortality, but also a high infant mortality in the second semester of the children lives, when it should decline, it was almost $1 / 3$, while in other countries was $1 / 5 .^{32}$ The infant mortality rate is a particularly good indicator of different levels of economic development. Historically observed,

24 "Demographic Problems of Southeastern Europe", Population Index 7, 2 (1941), 8492, DOI: $10.2307 / 3030705$

25 Statistički godišnjak I, 1929, 118; Statistički godišnjak II, 1930, (Beograd: Opšta državna statistika Kraljevine Jugoslavije, 1933), 68-69.

26 Low infant mortality was between $3-4.9 \%$, while more than $10 \%$ was considered as very high. (Matija Ambrožić, "Mortalitet dece u svetlosti zvaničnih statističkih godišnjaka“, Mortalitet i morbiditet dece u Jugoslaviji, referati sa I jugoslovenskog pedijatriskog kongresa na Bledu, ur. dr. Matija Ambrožić i dr. Milivoje Sarvan, (Beograd: Biblioteka centralnog higijenskog zavoda, 1936), 11)

27 See also data in: Ambrožić, "Mortalitet dece u svetlosti zvaničnih statističkih godišnjaka", 9-11; Б. Константиновић, Смртност одојчади и мале деце, (Београд: Централни хигијенски завод, 1932).

28 Josef Kytir, Rainer Münz, "Infant mortality in Austria - 1820-1950. Trends and regional patterns", The Decline of Infant Mortality in Europe, 1800-1950: Four national case studies, eds Pier Paolo Viazzo, Carlo A. Corsini, (Florence International Child Development Centre, 1993), 72.

29 Catherine Rollet, Patrice Bourdelais, „Infant mortality in France - 1750-1950. Evaluation and perspectives", The Decline of Infant Mortality, 63.

30 Hallie J. Kintner, "Determinants of Temporal and Areal Variation in Infant Mortality in Germany, 1871-1933", Demography 25, 4 (1988), 601, DOI: 10.2307/2061324

31 „Demographic Problems of Southeastern Europe“, 86-87.

32 Statistički godišnjak II, 1930, 68-69. - Besides the poor economic and social situation in Yugoslavia, the high mortality rate in the second half of the year can be explained by the fact that in some parts of country many parents didn't report newborns who had passed away in the first days and weeks of life. Ambrožić, "Mortalitet dece u svetlosti zvaničnih statističkih godišnjaka", 12-13. 
a reduction in infant and child mortality ${ }^{33}$ is the result of economically developed countries. ${ }^{34}$ Of course, there are various complex indicators such as maternal mortality (which ranged from 1930 to 1938 - 403 (MMR)), ${ }^{35}$ mortality in the age of reproduction (15-45), mortality of children before a productive age, and mortality of men who fail to survive the productive age (15-65). ${ }^{36}$

Differences in a population's age structure are also indicators of differences in the degree of economic development. The simplest measurement of differences in age structure is reflected in the percentage of the population under 15 or over 65 years of age. The first one is inversely and the second one directly related to the level of economic development. After World War II, the United Nations classified the world's nations into three categories, "old," "mature," and "young," "Old" nations are those with more than $7 \%$ of the population over the age of 65 and they are generally viewed as the most economically developed nations of the world. "Mature" countries, i.e. countries with $4 \%$ to $7 \%$ of the population over the age of 65 , are primarily countries in industrial transition or are considered to be nations with income per capita increasing and "young" nations are those with less than $4 \%$ of its population over the age of $65 .^{37}$

33 In addition to the infant mortality rate, there is also "late infant mortality rate" - that is, infant mortality (deaths during the first year of life) minus neonatal mortality (deaths during the first month of life). Late infant mortality is a more sensitive indicator because deaths in the first months of life are more attributable to biological and congenital forces than to economic and social factors. Infant deaths from the first to twelfth months reflect the impact of economic and social conditions (Hauser, "Demographic Indicators", 101).

34 Hauser, "Demographic Indicators", 101.

35 Calculated based on: Statistički godišnjak X, 1940, (Beograd: Opšta državna statistika Kraljevine Jugoslavije, 1941), 86, 95.

36 The aforementioned indices show the ability of one country to enable women to survive for the reproduction of the subsequent generation; to enable children to survive to a productive age; a as well as achieving a productive return on investment in the rearing of its population. Fertility, like mortality, may be utilized as an indicator of economic development, both as a component of population growth and a reflection of national differences in economic, social and political organization. The experience of economically more advanced countries in the world reveals a high reverse correlation between birth rates and levels of economic development - economically advanced nations are also characterized by decline in both fertility and mortality (Hauser, "Demographic Indicators", 101).

37 Hauser, "Demographic Indicators", 101. 
Chart 1: Age structure of the population of the Kingdom of SCS in 1921

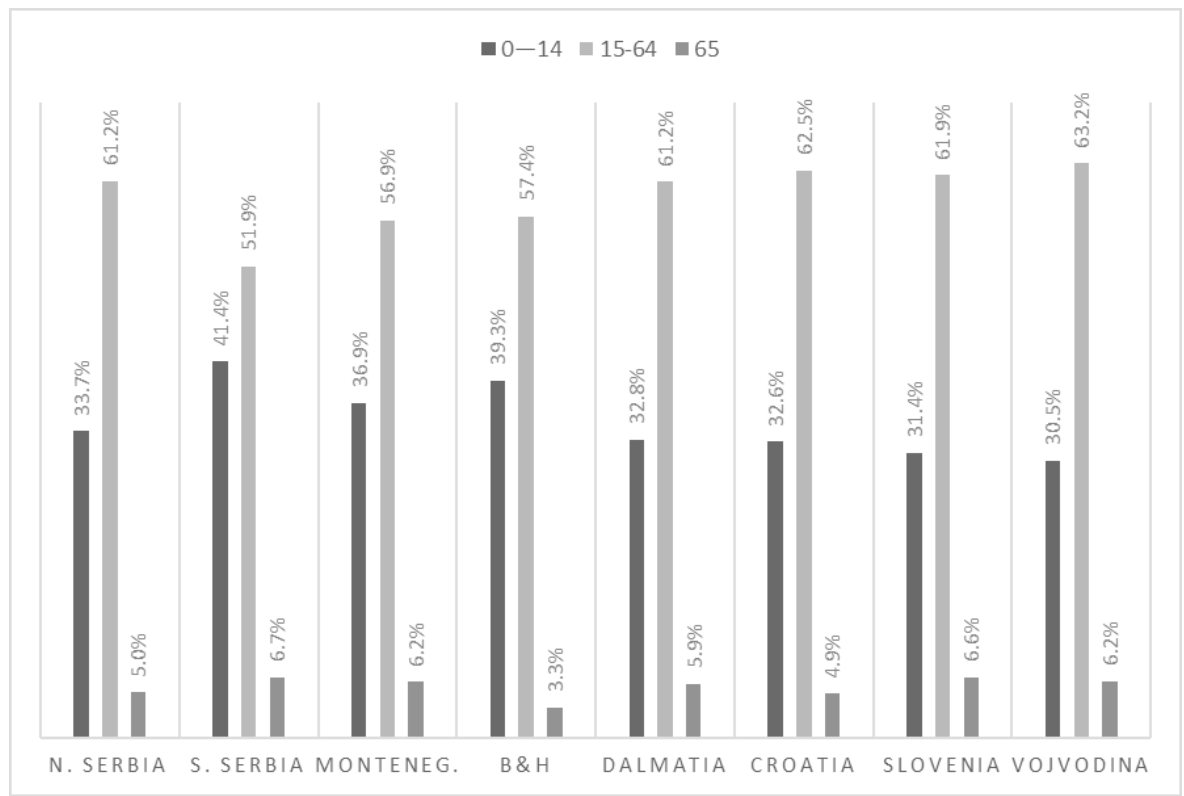

Source: Definitivni rezultati popisa stanovništva od 31. januara 1921. god, 368-379.

Chart 1 represents the age structure of the population of the Kingdom of SCS based on the 1921 census. Although the census was conducted in the period after the heavy casualties suffered in World War I, there are a few issues that need to be addressed. According to the above UN classification, the Kingdom of SCS with $5.6 \%$ of the population over the age of 65 should be classified as a "mature country" undergoing industrial transition. Slovenia had the highest proportion of elderly people, which corresponds to the fact that it was economically the most developed, as well as South Serbia, which owes its high percentage to the fact that it had smallest ratio of population betwen 15 and 65 year old (51.9). Also, the analysis of the age structure shows that the youngest provinces were South Serbia and Bosnia-Herzegovina, which was a consequence of the population's confessional and ethnic composition.

Due to the previously mentioned administrative changes, it was impossible to monitor the demographic changes continuously in terms of the population's age structure by territory, so for 1931 we were instructed to analyze the population by banovinas. Taking the Kingdom of SCS as a whole, the percentage of those over 65 years of age decreased to $5.1 \%$, 
and the percentage of the youngest population increased from $34.8 \%$ to $34.2 \%$, while the percentage of the working population increased from $59.9 \%$ to $60.7 \%$. Regionally considered - the Dravska banovina (Slovenia) had the highest segment of the elderly $-7.2 \%$, but also the lowest segment of the youngest $-30.4 \%$ (except for Belgrade), which justified its role demographically and statistically as the most economically developed region. The territories of South Serbia and Bosnia-Herzegovina, Vrbaska, Drinska and Vardarska banovina once again had the highest portion of young people, while the number of the elderly in the south of the country decreased, which in turn corresponds to the poorer economic situation in those parts.

Chart 2: Age structure of the population by banovinas in 1931

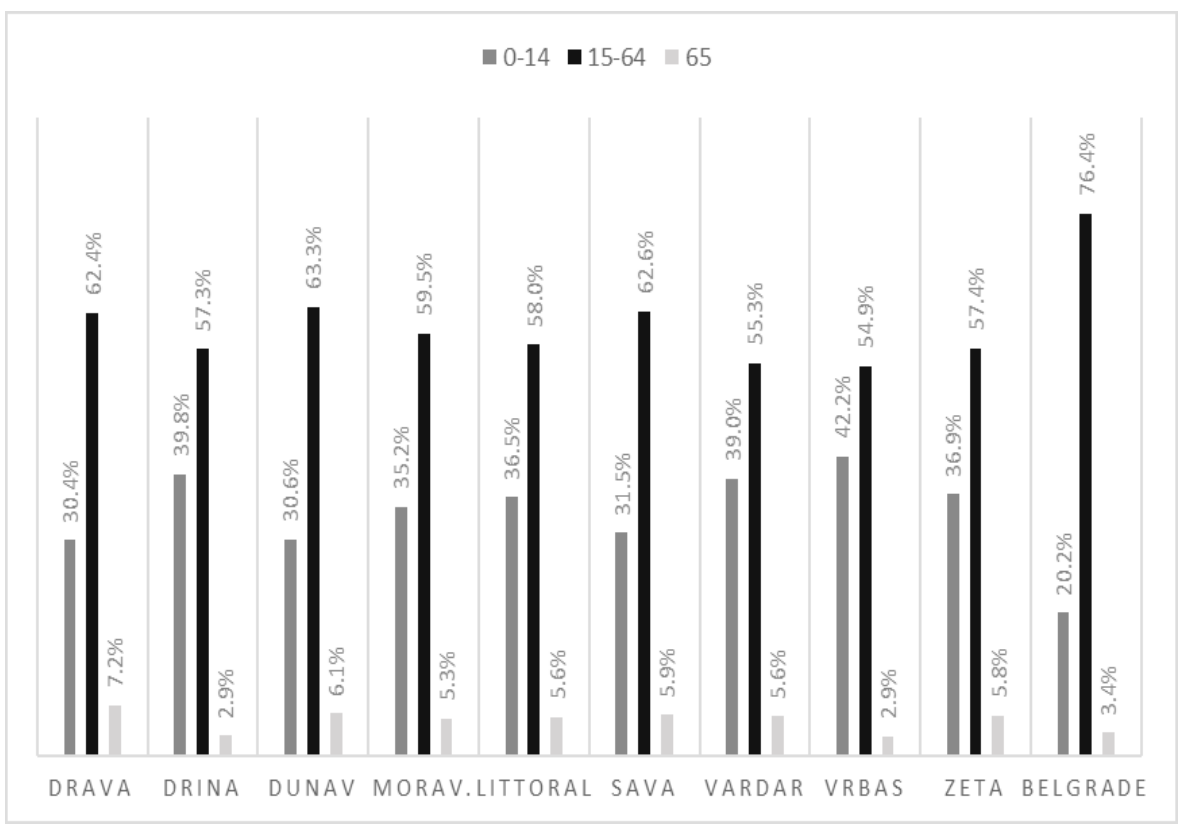

Source: Statistički godišnjak V, 1933, (Beograd: Opšta državna statistika Kraljevine Jugoslavije, 1935), 42-43.

Another index based on the population's age structure with direct economic significance is the so-called "dependency ratio." The dependency ratio is an age-population ratio of those typically not in the labor force and those typically in the labor force. In economy, the "depend- 
ent-age-population" are those who do not earn, i.e. the child population from 0 to 14 years of age and those over 65 , while the productive population is from 15 to 64 years of age. ${ }^{38}$ In the Kingdom of SCS, the overall dependency ratio was 68.5 , meaning that for every 100 productive people of 15 to 65 years of age, there were 68.5 unemployed, either children or the elderly. The employment ratios according to provinces were: 92.6 in South Serbia; 75.6 in Montenegro; 74.2 in Bosnia-Herzegovina; 63.3 in Dalmatia; 63.2 in North Serbia; 61.4 in Slovenia, 60 in Croatia and 58.1 in Vojvodina. ${ }^{39}$ Ten years later, the data was somewhat different, but it was more due to the fact that it was presented according to the new administrative and territorial division into banovinas than because of any changes in the structure itself, and it is therefore difficult to compare them in detail, although there are some similarities. The overall dependency ratio in the Kingdom of SCS dropped to 66.1, with the following individual values by banovinas: Vrbas - 82; Vardar - 80.7; Drina - 74,5; Zeta - 74.3; the Littoral - 72.6; Morava - 67.9; Drava - 60,3; Sava - 59,7; Danube 57,9; Belgrade $-30.8 .^{40}$

Distribution of the population in cities is also one of the indicators of economic status and development. Industrialization and urbanization, two closely related phenomena, can also be presented by the portion of the population living in the cities. Table 2 and Table 3 show the cities with more than 30,000 citizens during the 1920s, their growth, the annual growth rate, and the occupations of those employed. The total population living in the cities with over 30,000 inhabitants was 752,451 in 1921 and ten years later $1,077,023$, which is an increase of $43 \%$. Belgrade had the highest population growth, followed by Split, Zagreb, Skopje and Novi Sad.

Table 2: Cities with more than 30,000 citizens in 1921 and 1931

\begin{tabular}{|l|c|c|r|l|}
\hline & 1921 & 1931 & \multicolumn{1}{l|}{ Growth } & \multicolumn{1}{l|}{ CAGR } \\
\hline Belgrade & 114,753 & 238,775 & $108 \%$ & $7.60 \%$ \\
\hline Split & 25,045 & 43,711 & $75 \%$ & $5.73 \%$ \\
\hline
\end{tabular}

38 Allen C. Kelley, "Population Growth, the Dependency Rate, and the Pace of Economic Development", Population Studies, 27, 3, 1973, 405-406, DOI: 10.2307/2173761; Hauser, "Demographic Indicators", 112.

39 Definitivni rezultati popisa stanovništva od 31. januara 1921. god, 368-379.

40 Statistički godišnjak V, 1933, 42-43. 


\begin{tabular}{|l|r|r|r|l|}
\hline Zagreb & 108,674 & 185,581 & $71 \%$ & $5.50 \%$ \\
\hline Skopje & 40,666 & 68,334 & $68 \%$ & $5.33 \%$ \\
\hline Novi Sad & 44,237 & 63,985 & $45 \%$ & $3.76 \%$ \\
\hline Niš & 25,109 & 35,465 & $41 \%$ & $3.51 \%$ \\
\hline Sarajevo & 66,317 & 78,173 & $18 \%$ & $1.66 \%$ \\
\hline V. Bečkerek & 27,522 & 32,381 & $18 \%$ & $1.64 \%$ \\
\hline Osijek & 34,485 & 40,337 & $17 \%$ & $1.58 \%$ \\
\hline Bitolj & 28,420 & 33,024 & $16 \%$ & $1.51 \%$ \\
\hline Ljubljana & 53,294 & 59,765 & $12 \%$ & $1.15 \%$ \\
\hline Subotica & 90,961 & 100,058 & $10 \%$ & $0.96 \%$ \\
\hline Maribor & 30,662 & 33,131 & $8 \%$ & $0.78 \%$ \\
\hline Senta & 30,964 & 31,969 & $3 \%$ & $0.32 \%$ \\
\hline Sombor & 31,342 & 32,334 & $3 \% .31 \%$ \\
\hline
\end{tabular}

Sources: Statistički godišnjak I, 1929, 60; Statistički godišnjak VI, 1934-1935, (Beograd: Opšta državna statistika Kraljevine Jugoslavije, 1937), 51.

The connection between urbanization and industrialization is clearly shown in Table 3, including certain features specific to individual territories. City residents worked mostly in industries and crafts, with the highest segment of $43 \%$ in Niš and $42.7 \%$ in Osijek. Subotica and Sombor were an exception, with their residents, $51.6 \%$ and $39.4 \%$ respectively, being engaged primarily in agriculture, which is in line with the high agricultural production in the north of the Kingdom. Trade, credit and traffic were most prevalent in Skopje (24.9\%) and Maribor (28\%), with the largest number of employees in administration and other public services in Sarajevo (25.1\%), Belgrade (22.9\%) and Ljubljana (22.9\%). 
Table 3: Structure of the employed population in cities in 1931, by occupation

\begin{tabular}{|c|c|c|c|c|c|}
\hline City & $\begin{array}{c}\text { Agriculture, } \\
\text { forestry } \\
\text { and fisher- } \\
\text { ies }\end{array}$ & $\begin{array}{c}\text { Industry, } \\
\text { crafts }\end{array}$ & $\begin{array}{l}\text { Trade, } \\
\text { credit } \\
\text { traffic }\end{array}$ & $\begin{array}{c}\text { Public } \\
\text { service, free } \\
\text { professions, } \\
\text { military }\end{array}$ & Other \\
\hline Belgrade & $1.3 \%$ & $33.3 \%$ & $21.4 \%$ & $22.9 \%$ & $21.0 \%$ \\
\hline Split & $22.1 \%$ & $26.5 \%$ & $18.6 \%$ & $15.4 \%$ & $17.4 \%$ \\
\hline Zagreb & $2.9 \%$ & $37.9 \%$ & $21.9 \%$ & $17.8 \%$ & $19.5 \%$ \\
\hline Skopje & $15.0 \%$ & $29.3 \%$ & $24.9 \%$ & $18.2 \%$ & $12.6 \%$ \\
\hline Novi Sad & $18.6 \%$ & $31.9 \%$ & $21.0 \%$ & $18.5 \%$ & $10.1 \%$ \\
\hline Niš & $1.7 \%$ & $43.0 \%$ & $20.3 \%$ & $21.0 \%$ & $14.0 \%$ \\
\hline Sarajevo & $1.8 \%$ & $34.4 \%$ & $21.8 \%$ & $25.1 \%$ & $16.9 \%$ \\
\hline $\begin{array}{l}\text { V. Bečker- } \\
\text { ek }\end{array}$ & $19.3 \%$ & $35.4 \%$ & $19.3 \%$ & $10.7 \%$ & $15.2 \%$ \\
\hline Osijek & $6.2 \%$ & $42.7 \%$ & $19.5 \%$ & $15.6 \%$ & $16.0 \%$ \\
\hline Bitolj & $14.2 \%$ & $36.2 \%$ & $22.6 \%$ & $14.1 \%$ & $13.0 \%$ \\
\hline Ljubljana & $2.6 \%$ & $27.4 \%$ & $24.0 \%$ & $22.9 \%$ & $23.1 \%$ \\
\hline Subotica & $51.6 \%$ & $20.3 \%$ & $13.3 \%$ & $7.9 \%$ & $7.0 \%$ \\
\hline Maribor & $2.7 \%$ & $30.9 \%$ & $28.0 \%$ & $17.9 \%$ & $20.5 \%$ \\
\hline Sombor & $39.4 \%$ & $23.7 \%$ & $15.6 \%$ & $10.4 \%$ & $10.9 \%$ \\
\hline
\end{tabular}

Source: Statistički godišnjak IX, 1938-1939, (Beograd: Opšta državna statistika Kraljevine Jugoslavije, 1939), 20-35.

\section{Economic indicators}

So far, we have analyzed the indirect economic indicators of the population structure in censuses, and now we will analyze two direct models enabled by data published in two censuses - the first, economi- 
cally active and economically inactive citizens and structure of the population by occupation.

According to present-day definitions, the basic characteristics of the economic structure of the population are occupation, status, and field of operation. The difference between the aforementioned categories is as follows: occupation is the type of work a person does in everyday life, status is the social position a person acquires through his/her work, and the third is the field of operation. The censuses of 1921 and 1931 confused occupation and field of operation, but the data presented under subsequent terminology and classification are more fields of operation than occupations, and they will be treated as such in this paper. ${ }^{41}$ Also, in censuses, employed persons were registered by their main occupation and the elderly by their occupation. Considering the methodology of data collection, these two approaches provided somewhat different results but not sufficiently different to generate significant deviations. ${ }^{42}$

Table 4: Structure of economically active and inactive population in 1921 and 1931 by occupation

\begin{tabular}{|c|c|c|c|c|c|c|c|}
\hline & & & $\begin{array}{l}\text { Agriculture, } \\
\text { forestry, } \\
\text { fisheries }\end{array}$ & $\begin{array}{l}\text { Industry, } \\
\text { crafts }\end{array}$ & $\begin{array}{l}\text { Trade, } \\
\text { credit, } \\
\text { traffic }\end{array}$ & $\begin{array}{c}\text { Public } \\
\text { service, free } \\
\text { professions, } \\
\text { military }\end{array}$ & Other \\
\hline \multirow{6}{*}{$\begin{array}{l}\text { Working } \\
\text { population }\end{array}$} & \multirow{3}{*}{1921} & M & $59 \%$ & $84 \%$ & $81 \%$ & $83 \%$ & $50 \%$ \\
\hline & & $\mathrm{F}$ & $41 \%$ & $16 \%$ & $19 \%$ & $17 \%$ & $50 \%$ \\
\hline & & $\mathrm{T}$ & $4,848,438$ & 522,091 & 207,728 & 245,942 & 208,912 \\
\hline & \multirow{3}{*}{1931} & M & $63 \%$ & $83 \%$ & $83 \%$ & $79 \%$ & $52 \%$ \\
\hline & & $\mathrm{F}$ & $37 \%$ & $17 \%$ & $17 \%$ & $21 \%$ & $48 \%$ \\
\hline & & $\mathrm{T}$ & $5,098,888$ & 717,002 & 272,349 & 305,770 & 288,606 \\
\hline
\end{tabular}

41 Mladenović, Đolević, Šoškić, Ekonomska statistika, 48-55.

42 Employed persons classified by occupation give a slightly higher number when it comes to employment in agriculture, because women who worked were also counted, while according to the second criterion the results are slightly lower. In the first case it was $80.4 \%$ and in the second case it was $75.9 \%$ in 1921. Mijo Mirković, Ekonomska historija Jugoslavije 1918-1941, (Zagreb: Informator, 1968), 303, 304. 


\begin{tabular}{|c|c|c|c|c|c|c|c|}
\hline \multirow{6}{*}{$\begin{array}{l}\text { Non-working } \\
\text { population }\end{array}$} & \multirow{3}{*}{1921} & M & $36 \%$ & $29 \%$ & $29 \%$ & $29 \%$ & $32 \%$ \\
\hline & & $\mathrm{F}$ & $64 \%$ & $71 \%$ & $71 \%$ & $71 \%$ & $68 \%$ \\
\hline & & $\mathrm{T}$ & $4,367,076$ & 635,667 & 301,051 & 197,588 & 150,274 \\
\hline & \multirow{3}{*}{1931} & M & $35 \%$ & $30 \%$ & $30 \%$ & $30 \%$ & $29 \%$ \\
\hline & & $\mathrm{F}$ & $65 \%$ & $70 \%$ & $70 \%$ & $70 \%$ & $71 \%$ \\
\hline & & $\mathrm{T}$ & $5,571,677$ & 816,050 & 403,617 & 262,066 & 198,013 \\
\hline \multirow[t]{2}{*}{ Total } & 1921 & & $9,215,514$ & $1,157,758$ & 508,779 & 443,530 & 359,186 \\
\hline & 1931 & & $10,670,565$ & $1,533,052$ & 675,966 & 567,836 & 458,619 \\
\hline \multirow{2}{*}{\multicolumn{2}{|c|}{$\begin{array}{l}\% \text { of the total number oc- } \\
\text { cupation }\end{array}$}} & & $78.9 \%$ & $9.9 \%$ & $4.4 \%$ & $3.8 \%$ & $3.1 \%$ \\
\hline & & & $76.7 \%$ & $11.0 \%$ & $4.9 \%$ & $4.1 \%$ & $3.3 \%$ \\
\hline \multirow{2}{*}{\multicolumn{2}{|c|}{$\begin{array}{l}\text { Number of working per } \\
100 \text { persons }\end{array}$}} & & 52.6 & 45.1 & 40.8 & 55.5 & 58.2 \\
\hline & & & 47.8 & 46.8 & 40.3 & 53.8 & 62.9 \\
\hline
\end{tabular}

Sources: Statistički godišnjak I, 1929, 90-93; Statistički godišnjak VIII, 1937, (Beograd: Opšta državna statistika Kraljevine Jugoslavije, 1938), 60-61.

The total agricultural population was 9.2 million (78.9\%) in 1921, and 10.6 million (76.7\%) in 1931 . Over those ten years, the population increased by almost 2 million and the agricultural population by 1.4 million. ${ }^{43}$ There were significant differences between the regions of the Kingdom, so the highest agricultural population compared to the total population was $14 \%(2,037,165)$ in the Savska banovina, followed by $12 \%(1,783,552)$ in the Dunavska banovina, and $4.95 \%$ in the Dravska banovina $(689,772){ }^{44}$

The obvious increase in the workforce in agriculture was a double-edged sword: on the one hand it was a factor of economic growth, but on the other hand, due to the underdeveloped economy, a huge number of workers became an overload for the agriculture.

In order to make the demographic structure complete, it is necessary to present the population density per hectare of agricultural land, that is, arable land per person involved in agriculture. Data on the number of agricultural population per hectare differs in sources and literature,

43 Statistički godišnjak I, 1929, 57, 90; Statistički godišnjak IV, 1932, 41; Statistički godišnjak VII, 1936, (Beograd: Opšta državna statistika Kraljevine Jugoslavije, 1937), 35; Statistički godišnjak X, 1940, 84.

44 Statistički godišnjak VIII, 1937, 18-57; See also: Nikola Vučo, Poljoprivreda Jugoslavije, (Beograd: Rad, 1958), 15-16. 
but all authors agree that a considerable share of the agricultural population was redundant. According to the census in 1931, there were 77.4 farmers per square kilometer of cultivated land (100 hectares), compared to 81.6 farmers in $1937 .{ }^{45}$ Based on these figures, Wilbert Moore calculated that the surplus agricultural population in Yugoslavia was 61.5\%, and Jozo Tomašević $43 \%(5,001,000){ }^{46}$

The surplus agricultural population caused the emergence of agrarian overpopulation, ${ }^{47}$ that is, hidden unemployment, which brought along socio-economic problems, with a particular impact on the creation of capital and modernization of agriculture. Based on the population structure and demographic trends, it can be easily noted that there was an increase in the population, above all agricultural, which meant an increase in the workforce in the agrarian sector and the pressure of population on the land because the undeveloped industry was unable to absorb them. Agrarian overpopulation thus led to low wages, low incomes, low labor productivity, and low consumption. Technical progress was also hindered because there was no surplus capital to invest in agricultural mechanization. ${ }^{48}$

"Agrarian overpopulation," which according to Michael Kopsidis is poorly defined, is a phenomenon that most other contemporary historians view in the context of an inability of economic growth because the rural population is holding it back. This view is inevitably accompanied by low productivity and the fact that population growth was considered as one of the factors for the impossibility of greater investment, which prevented the creation of capital. ${ }^{49}$

45 It was similar in Bulgaria and 81.59 in Romania. In Canada, only there were only 11 inhabitants on 100 acres, 17 in America, about 30 in England, 36 in Denmark, 48 in France, 52 in Germany (Ратибор Поповић, Аграрна пренасељеност Југославије, (Београд: Правни факултет, 1940), 48-50; Vučo, Poljoprivreda Jugoslavije, 60).

46 Jozo Tomasevich, Peasants, politics, and economic change in Yugoslavia, (Stanford: Stanford University Press, 1955), 310-311; Wilbert E. Moore, Economic Demography of Eastern and Southern Europe, (New York: Arno Press, 1972), 63-64.

47 A condition comprising a series of symptoms that directly or indirectly arise from disproportion of agricultural population and the available means for a strong increase in the population component (Поповић, Аграрна пренасељеност, 13).

48 Ivan T. Berend, "Agriculture", The economic history of Eastern Europe: 1919-1975, Vol. 1: Economic structure and performance between the two Wars, eds Michael C. Kaser, Edward A. Radice, (Oxford: Clarendon Press, 1985), 184-185.

49 Michael Kopsidis, "Missed Opportunity or Inevitable Failure? The Search for Industrialization in Southeast Europe 1870-1940", Working Papers, European Historical Economics Society working papers in economic history, 19, 2012, 11, date of access 20.5. 2019, http://www.ehes.org/EHES_No19.pdf 
The aforementioned data indicates that the working population was not a real factor of agricultural growth. Unemployment was responsible for hunger and poverty in the country, which posed not only an economic, but also a social problem. Moreover, mass unemployment hindered technical development, competitiveness, innovation, and therefore productivity development. The enormous availability of the working population made it unnecessary to introduce expensive machines into the production process, and over time, the replacement of human labor by machines became expensive. One of the far-reaching socio-economic consequences of agricultural overpopulation was the negative impact on the creation of capital in peasant households. ${ }^{50}$

Under the given demographic circumstances, employees and dependents in other fields of operation accounted for a smaller number of employees: in industry and crafts they made up about $9.9 \%$ and $11 \%$ of the population, in trade and traffic $4.4 \%$ and $4.9 \%$, in public professions $3.8 \%$ and $4.1 \%$ respectively. These results testify to the presence of industrialization and urbanization. However, in comparison to industrialized European countries, this growth was unnoticeable.

These numbers correspond to the fact that the industrial sector was a relatively small segment of the real economy, so it did not have a greater impact on its structure in the entire interwar period. Forestry made up $7.90 \%$ of the national income, the extractive industry $1.8 \%$, the manufacturing industry $11.6 \%$, construction $1.10 \%$, and crafts amounted to $10.6 \%{ }^{51}$ On top of these quantitative indicators, there were also qualitative ones: insufficient and outdated mechanization, the inadequacy of economic legislation, the lack of capital and affordable loans, an unskilled workforce, dependence on foreign investments, small demand and supply of industrial products, and poor infrastructure.

\section{Conclusion}

An analysis of the economic structure of the population from a demographic and economic point of view has pointed to several conclusions that contribute to the thesis of an underdeveloped economy, a predominantly agricultural population, and structural problems of the Kingdom of SCS/Yugoslavia. Differences in regional structures are noticeable in all

50 Berend, "Agriculture", 186-187.

51 В. М. Ђуричић, М. Б. Тошић, А. Вегнер, П. Рудченко, М. Р. Ђорђевић, Наша народна привреда и национални приход, (Сарајево: Државна штампарија, 1927), 265. 
the analyzed indicators: the economically more developed provinces of Slovenia, Croatia, and Vojvodina had a lower natural increase, a more elderly population, and a lower dependency ratio of employed inhabitants, while Bosnia-Herzegovina and the south of the country had a high natural increase of the young population and high unemployment.

Generally observed, the analyses show that the Kingdom of Yugoslavia maintained a high rate of growth, being in the second phase of a demographic transition. The causes of mortality and an average mortality rate, as well as infant mortality rates, indicate poorer economic conditions in the country, but better in relation to the region. According to the population's age structure, the Kingdom, with 5.6\% of the population over 65, was among the "mature countries," in a state of industrial transition. The distribution of the population in cities and their employment reflected the regional specificities of individual provinces, as well as some urbanization and industrialization. Undoubtedly, the population by activity was predominantly agrarian, which, with the dedication of the population and the emergence of agrarian overpopulation, on the one hand, was less a factor of economic growth and more of an overload. Employees in other industries had seen some growth over the decade, but not enough to account for any major structural changes.

\section{Summary}

This paper presents the economic structure of the population in the Kingdom of Serbs, Croats, and Slovenes based on the censuses of 1921 and 1931 at the demographic and economic levels through an analysis of various indicators. The analysis distinguishes several conclusions that contribute to the thesis of an underdeveloped economic country, with s mainly agricultural population and numerous structural problems. The Kingdom of SCS had a high rate of growth, being in the second phase of demographic transition. The causes of mortality, the average mortality rate, and infant mortality rates indicate inferior economic conditions in the country. According to the population's age structure, the Kingdom, with $5.6 \%$ of the population over 65 , was among the "mature countries," as a country on a level of industrial transition. The distribution of the population in cities reflected the regional specificities of individual provinces, as well as the existence of some urbanization and industrialization. Undoubtedly, the population by activity was predominantly agrarian (77-78\%) and overpopulated $(43 \%-61.5 \%)$, which was less a factor of economic growth and 
more of an overload. Employees in other industries did see some growth (in industry from $9.9 \%$ to $11 \%$ of the population, etc...), over the decade, but not enough for structural changes. Differences in regional structures are noticeable: economically more developed provinces, Slovenia, Croatia, and Vojvodina, had a lower natural increase, a more elderly population, and a lower dependency ratio of employed inhabitants, while Bosnia-Herzegovina and the south of the country had a high natural increase, a young population, and high unemployment.

\section{Sources and Literature}

- Definitivni rezultati popisa stanovništva od 31. januara 1921. god. Beograd: Opšta državna statistika, Sarajevo: Državna štamparija, 1932.

- Godišnjak Kraljevine Srba, Hrvata i Slovenaca 1926, ur. Dobr. Stošović. Beograd: H. T. Montague bell, 1926. (cyrillic)

- Statistički godišnjak I, 1929. Beograd: Opšta državna statistika Kraljevine Jugoslavije, 1932.

- Statistički godišnjak II, 1930. Beograd: Opšta državna statistika Kraljevine Jugoslavije, 1933.

- Statistički godišnjak IV, 1932. Beograd: Opšta državna statistika Kraljevine Jugoslavije, 1934.

- Statistički godišnjakV,1933. Beograd: Opšta državna statistika Kraljevine Jugoslavije, 1935.

- $\quad$ Statistički godišnjak VI, 1934-1935. Beograd: Opšta državna statistika Kraljevine Jugoslavije, 1937.

- Statistički godišnjak VII, 1936. Beograd: Opšta državna statistika Kraljevine Jugoslavije, 1937.

- $\quad$ Statistički godišnjak VIII, 1937. Beograd: Opšta državna statistika Kraljevine Jugoslavije, 1938.

- $\quad$ Statistički godišnjak IX, 1938-1939. Beograd: Opšta državna statistika Kraljevine Jugoslavije, 1939.

- Statistički godišnjak X, 1940. Beograd: Opšta državna statistika Kraljevine Jugoslavije, 1941.

- Службене новине Краљевине Срба, Хрвата и Словенаца, 1922.

- Службене новине Краљевине Југославије, 1929.

- Ambrožić, Matija. "Mortalitet dece u svetlosti zvaničnih statističkih godišnjaka“. Mortalitet i morbiditet dece u Jugoslaviji, referati sa I jugoslovenskog pedijatriskog kongresa na Bledu, ur. dr. Matija Ambrožić i dr. Milivoje Sarvan, 9-61. Beograd, Biblioteka centralnog higijenskog zavoda 1936.

- $\quad$ Berend, Ivan T. "Agriculture". The economic history of Eastern Europe: 19191975, Vol. 1: Economic structure and performance between the two Wars, eds Michael C. Kaser, Edward A. Radice. Oxford: Clarendon Press, 1985. 
- Bubalo-Živković, Milka, Bojan Đerčan. "Demographic changes in the Kingdom of SCS and the Kingdom of Yugoslavia”. Istorija i geografija: susreti $i$ prožimanja, ur. Sofija Božić, 299-317. Beograd: Institut za noviju istoriju Srbije, Geografski institut "Jovan Cvijić” SANU, Institut za slavistku RAN, 2014. (cyrillic)

- $\quad$ Čalić, Mari Žanin. Socijalna istorija Srbije 1815-1941: usporeni napredak u industrijalizaciji. Beograd: Clio, 2004. (cyrillic)

- „Demographic Problems of Southeastern Europe“. Population Index 7, 2, 1941, 84-92.

- $\quad$ Đuričić, V. M., M. B. Tošić, A. Vegner, P. Rudčenko, M. R. Đorđević. Naša narodna privreda i nacionalni prihod. Sarajevo: Državna štamparija, 1927. (cyrillic)

- Dimitrijević, Sergije. Privredni razvitak Jugoslavije od 1918-1941 godine. Beograd: Visoka škola političkih nauka, 1961.

- Gaćeša, Nikola L. "Demografske i socijalne prilike u vreme prisajedinjenja Vojvodine Kraljevini Srbiji 1918. godine”. Prisajedinjenje Vojvodine Kraljevini Srbiji 1918, 49-57. Novi Sad: Muzej Vojvodine, Institut za istoriju Filozofskog fakulteta, 1993. (cyrillic)

- Gaćeša, Nikola L. Radovi iz agrarne istorije i demografije. Novi Sad: Matica srpska, 1995. (cyrillic)

- $\quad$ Haupt, Heinz-Gerhard, Jurgen Kocka. "Historijska poredba: metode, zadaci i problemi. Uvod". Uvod u komparativnu historiju, prir. Drago Roksandić, 147176. Zagreb: Golden marketing - Tehnička knjiga, 2004.

- Hauser, Philip M. "Demographic Indicators of Economic Development". Economic Development and Cultural Change 7, 2, 1959, 98-116. DOI: $10.1086 / 449786$

- $\quad$ Ilievski, Borče. "Turci u Kraljevini SHS/Jugoslaviji. Demografska analiza na osnovu popisa stanovništva 1921. i 1931". Istorija 20. veka 1/2018, 35-54. DOI: 10.29362/ist.20veka.2018.1.ili.35-54

- Isić, Momčilo. Socijalna i agrarna struktura Srbije u Kraljevini Jugoslaviji: (prema popisu stanovništva od 31. marta 1931. godine). Beograd: Institut za noviju istoriju Srbije, 1999. (cyrillic)

- Jagodić, Miloš, Ognjen Radonjić. „Pyrrhic Victory: The Great War and its Immediate Consequences for Serbia's Economy“. The Economic Causes and Consequences of the World War I, eds Ivan Vujačić, Mihail Arandarenko. Belgrade: Ekonomski fakultet, Centar za izdavačku delatnost, 2015, 219-235.

- Jagodić, Miloš. „Procena demografskih gubitaka Srba u periodu 1910-1921. godine“. Srpske studije 6/2015, 11-65. (cyrillic)

- Janjetović, Zoran. Deca careva, pastorčad kraljeva, Nacionalne manjine u Jugoslaviji 1918-1945. Beograd: Institut za noviju istoriju Srbije, 2005.

- Jovanović, Vladan. "Demografske odlike Vardarske banovine i problemi samoidentifikacije”. Etnoantropološki problem 2/2012, 563-584. (cyrillic) 
- $\quad$ Kelley, Allen C. "Population Growth, the Dependency Rate, and the Pace of Economic Development”. Population Studies 27, 3, 1973, 405-414, DOI: $10.2307 / 2173761$

- $\quad$ Kintner, Hallie J., "Determinants of Temporal and Areal Variation in Infant Mortality in Germany, 1871-1933". Demography 25, 4, 1988, 597-609. DOI: $10.2307 / 2061324$

- $\quad$ Kočović, Bogoljub. Etnički i demografski razvoj u Jugoslaviji od 1921. do 1991. godine: (po svim zvaničnim a u nekim slučajevima i korigovanim popisima), sv. 1. Paris: Association Dialogue, 1998.

- $\quad$ Konstantinović, B. Smrtnost odojčadi i male dece. Beograd: Centralni higijenski zavod, 1932. (cyrillic)

- $\quad$ Kopsidis, Michael. "Missed Opportunity or Inevitable Failure? The Search for Industrialization in Southeast Europe 1870-1940". Working Papers, European Historical Economics Society working papers in economic history, 19, 2012, 11. Date of access 20.5. 2019. http://www.ehes.org/EHES_No19.pdf

- Kukoleča, Stevan. Industrija Jugoslavije 1918-1938. Beograd: Balkanska štampa, 1941.

- $\quad$ Kuznets, Simon. Economic Growth and Structure. London: Heinemann Educational Books, 1966.

- $\quad$ Kuznets, Simon. "Population and Economic Growth". Proceedings of the American Philosophical Society, 111, 3, Population Problems, 1967, 170-193.

- $\quad$ Kytir, Josef, Rainer Münz. "Infant mortality in Austria - 1820-1950. Trends and regional patterns". The Decline of Infant Mortality in Europe, 1800-1950: Four national case studies, eds Pier Paolo Viazzo, Carlo A. Corsini, 71-86. Florence International Child Development Centre, 1993.

- $\quad$ Lakatoš, Joso. Jugoslavija u svijetlu statistike. Zagreb: Tisak hrvatskog štamparskog zavoda, 1919.

- $\quad$ Mirković, Mijo. Ekonomska struktura Jugoslavije: 1918-1941. Zagreb: Školska knjiga, 1952.

- $\quad$ Mirković, Mijo. Ekonomska historija Jugoslavije 1918-1941. Zagreb: Informator, 1968.

- $\quad$ Mladenović, Dragoslav, Vladislav Đolević, Dejan Šoškić. Ekonomska statistika. Beograd: Centar za izdavačku delatnost Ekonomskog fakulteta, 2008.

- Moore, Wilbert E. Economic Demography of Eastern and Southern Europe. New York: Arno Press, 1972.

- Paskojević, Miroslav. „Statistička služba u Jugoslaviji“. Socijalni arhiv8/1937, 159-160.

- Popović, Ratibor. Agrarna prenaseljenost Jugoslavije. Beograd: Pravni fakultet, 1940. (cyrillic)

- $\quad$ Radovanović, Svetlana. "Dva veka popisne statistike u Srbiji". Demografija 2/2005, 33-43. (cyrillic) 
- $\quad$ Radovanović, Svetlana. "Etnička struktura Kraljevine Jugoslavije u kontekstu nacionalne politike jugoslovenstva". Demografija IV/2007, 129-140. (cyrillic)

- $\quad$ Rollet, Catherine, Patrice Bourdelais. "Infant mortality in France - 17501950. Evaluation and perspectives". The Decline of Infant Mortality in Europe, 1800-1950: Four national case studies, eds Pier Paolo Viazzo, Carlo A. Corsini, 51-70. Florence International Child Development Centre, 1993.

- Sokolovska, Valentina. Ekonomska struktura stanovništva Republike Srbije. Novi Sad: Filozofski fakultet, 2018. Date of access 25. 8. 2019. http://digitalna.ff.uns.ac.rs/sadrzaj/2018/978-86-6065-469-6)

- $\quad$ Stavrijanos, Leften. Balkan posle 1453. godine. Beograd: Equilibrium, 2005.

- Stockwell, Edward G. "Fertility, Mortality, and Economic Status of Underdeveloped Areas". Social Forces 41, No. 4, 1963, 390-395.

- Tomasevich, Jozo. Peasants, politics, and economic change in Yugoslavia. Stanford: Stanford University Press, 1955.

- Vučo, Nikola. Poljoprivreda Jugoslavije. Beograd: Rad, 1958. 


\title{
Резиме
}

Јелена Рафаиловић

\section{Економска структура становништва Краљевине CXC}

\begin{abstract}
Апстракт: У раду је представљена економска структура становништва Краљевине Срба, Хрвата и Словенаца/Југославије на основу података два пописа, из 1921. и 1931. године. Тема је обрађена на демографском и економском нивоу кроз анализе различитих индикатора, са циљем да се млада држава представи кроз статистику основног економског сегмента, а ради разумевања привредног и социјалног стања.
\end{abstract}

Кључне речи: Краљевина СХС, становништво, демографија, економија, попис

У раду је представљена економска структура становништва Краљевине Срба, Хрвата и Словенаца/Југославије на основу података два пописа, из 1921. и 1931. године, на демографском и економском нивоу кроз анализу различитих показатеља. Резултати анализе указају на неколико закључака који доприносе тези о Краљевини Југославији као неразвијеној економској држави, са доминантним пољопривредним становништвом и бројним структурним проблемима. Са високом стопом раста становништва Краљевина је била у другој фази демографске транзиције, али просечна стопа смртности, стопа смртности одојчади и узроци смртности указују на слабије економске услове у земљи. Према старосној структури, са 5,6\% становништва старијег од 65 година спадала је у групу земаља које се могу окарактерисати као „зреле земље“, односно државе у индустријској транзицији. Расподела становништва у градовима је одражавала регионалне специфичности појединих покрајина, као и постојећи ниво урбанизације и индустријализације. Несумњиво, становништво је, према занимању, било претежно аграрно (77-78\%) и пренасељено (43-61,5\%), што је био мање фактор економског раста, а више преоптерећења. Запослени у другим индустријама су имали одређен раст током деценије, али недовољно за структурне промене (у индустрији од 9,9\% до 11\%, у трговини 4,4\% до 4,9\%). Разлике у регионалним структурама су јасно уочљиве: економски развијеније по- 
крајине, Словенија, Хрватска и Војводина, имале су мањи природни прираштај, старије становништво, нижи степен зависности запослених, а Босну и Херцеговину и југ земље карактерисали су висок природни прираштај, младо становништво и висока незапосленост. 